\title{
Characterization and Identification of Marine Alteromonas nigrifaciens Strains and Emendation of the Description
}

\author{
ELENA P. IVANOVA,,${ }^{1,2 *}$ ELENA A. KIPRIANOVA,${ }^{3}$ VALERY V. MIKHAILOV, ${ }^{1}$ GALINA F. LEVANOVA, ${ }^{4}$ \\ ALEXANDRA D. GARAGULYA,${ }^{3}$ NATALIYA M. GORSHKOVA, ${ }^{1}$ NOBORU YUMOTO, ${ }^{2}$ \\ AND SUSUMU YOSHIKAWA ${ }^{2}$ \\ Pacific Institute of Bioorganic Chemistry, Far Eastern Branch of the Russian Academy of Sciences, 690022, \\ Vladivostok, ${ }^{1}$ and Institute of Epidemiology and Microbiology, 603600, N. Novgorod, ${ }^{4}$ Russia; \\ Zabolotny Institute of Microbiology and Virology, Ukrainian Academy of Sciences, 252143, \\ Kiev, Ukraine ${ }^{3}$; and Osaka National Research Institute, \\ AIST, Ikeda, Osaka 563, Japan ${ }^{2}$
}

\begin{abstract}
Nine nonpigmented strains of gram-negative, aerobic, marine bacteria with polar flagella were isolated from the mussels Crenomytilus grayanus and Patinopecten jessoensis. These organisms were conspecific and exhibited relatively high levels of genetic relatedness $(61$ to $100 \%)$. The $G+C$ contents of the DNAs of these strains were 38.5 to $40.2 \mathrm{~mol} \%$. The strains isolated from mussels were phenotypically distinct from previously described Alteromonas species that have similar DNA G+C contents (Alteromonas haloplanktis, Alteromonas tetraodonis, Alteromonas atlantica, and Alteromonas carrageenovora), and their DNAs exhibited only 12 to $41 \%$ similarity with the DNAs of the type strains of these species. DNA-DNA hybridization data revealed that the levels relatedness between the strains which we studied and the type strain of Alteromonas nigrifaciens were significant (66 to 70\%). Production of a melanin-like pigment, which is characteristic of $A$. nigrifaciens, was observed only in tyrosine-containing media. The strains isolated from mussels were identified as $A$. nigrifaciens. We present an emended description of $\boldsymbol{A}$. nigrifaciens that includes several phenotypic and chemotaxonomic characteristics.
\end{abstract}

The genus Alteromonas Baumann et al. 1972 includes both nonpigmented and pigmented gram-negative, aerobic, polarly flagellated, marine bacterial species $(4,5,7,11)$, and there have been numerous proposals of new Alteromonas species recently $(3,10,12,16,22)$. However, phenotypic discrimination of the species of this genus is problematic because of significant variations in their phenotypic traits. Phenotypic differences are frequently observed among even genetically closely related strains (2). Tests to determine utilization of specific carbon sources, which have been used successfully in Pseudomonas systematics (9), are less informative when they are used for differentiation of Alteromonas species. Some characteristics, such as requirements for growth factors and the production of pigments and some secondary metabolites, which were described as specific characteristics of certain species, have been shown to be strain-specific characteristics in recent studies. For example, one strain of Alteromonas tetraodonis produces tetrodotoxin, and recent investigations of the DNA relatedness of Alteromonas species have shown that $A$. tetraodonis is closely related genetically to Alteromonas haloplanktis, which never produces tetrodotoxin (10). Thus, genetic and chemotaxonomic methods appear to provide more reliable information than differential phenotypic characteristics in Alteromonas systematics.

We previously isolated several strains belonging to the genus Alteromonas from the Far Eastern mussels Crenomytilus grayanus and Patinopecten jessoensis (13). The purpose of this study was to characterize and identify these strains by using phenotypic, genetic, and chemotaxonomic methods in order to provide additional taxonomic data for Alteromonas species.

\footnotetext{
* Corresponding author. Mailing address: Department of Organic Materials, Osaka National Research Institute, AIST, Ikeda, Osaka 563, Japan. Fax: 81-727-51-9628. Electronic mail address: ivep@onri go.jp.
}

\section{MATERIALS AND METHODS}

Bacterial strains and isolation. The strains which we used are listed in Table 1. Mussels (C. grayanus and P. jessoensis) were collected in 1989 and 1990 at the Pacific Institute Bio-Organic Chemistry Marine Experimental Station, Troitza Bay, Gulf of Peter the Great, Sea of Japan. The mussels were collected at a depth of $8 \mathrm{~m}$ (salinity, $33 \% \circ$; temperature, $12^{\circ} \mathrm{C}$ ) and were prepared aseptically. Each sample of tissue ( 3 to $5 \mathrm{~g}$ ) was homogenized in 10 to $15 \mathrm{ml}$ of sterile seawater in a sterile glass homogenizer. Then 0.1 to $0.2 \mathrm{ml}$ of the homogenate was spread onto plates containing marine agar 2216 (Difco) (1) and plates containing medium B, which contained $0.2 \%$ (wt/vol) Bacto Peptone (Difco), $0.2 \%$ (wt/vol) casein hydrolysate (Merck), $0.2 \%$ (wt/vol) yeast extract (Difco), $0.1 \%$ (wt/vol) glucose, $0.02 \%$ (wt/vol) $\mathrm{KH}_{2} \mathrm{PO}_{4}, 0.005 \%(\mathrm{wt} / \mathrm{vol}) \mathrm{MgSO}_{4} \cdot 7 \mathrm{H}_{2} \mathrm{O}, 1.5 \%(\mathrm{wt} / \mathrm{vol})$ Bacto Agar (Difco), $50 \%$ (vol/vol) natural seawater, and $50 \%$ distilled water. The $\mathrm{pH}$ of the medium was adjusted to 7.8 with $1 \mathrm{M} \mathrm{NaOH}$. All of the plates were incubated at 25 to $28^{\circ} \mathrm{C}$. The strains were isolated from single colonies after 7 days of incubation, purified (14), and stored on the same semisolid medium in tubes under mineral oil at $4^{\circ} \mathrm{C}$.

Phenotypic analysis. The phenotypic characteristics of each strain were determined by the methods described by Baumann et al. $(4,5)$ and Smibert and Krieg (23). The following physiological and biochemical properties were examined: oxidation or fermentation of glucose (18); arginine dihydrolase, lysine decarboxylase, and ornithine decarboxylase activities; accumulation of poly- $\beta$-hydroxybutyrate; cell pigmentation; cell morphology; Gram staining; motility; sodium requirement; oxidase (17), catalase, urease, indole, and $\mathrm{H}_{2} \mathrm{~S}$ production; and the ability to hydrolyze gelatin, starch. Tween 80 , and chitin. The requirement for $\mathrm{Na}^{+}$ions was determined on medium that contained $0.25 \%$ (wt/vol) yeast extract, $0.1 \%$ (wt/vol) glucose, $0.02 \%$ (wt/vol) $\mathrm{KH}_{2} \mathrm{PO}_{4}$, and $0.005 \%(\mathrm{wt} / \mathrm{vol})$ $\mathrm{MgSO}_{4} \cdot 7 \mathrm{H}_{2} \mathrm{O}(\mathrm{pH} 7.8)$. The tests for utilization of various organic substrates as sole carbon sources (at a concentration of $0.1 \%$ [wt/vol]) were performed on synthetic solid BM medium (4). In some cases liquid BM medium $(10 \mathrm{ml}$ per tube) was used; the bacteria were grown with shaking on a rotary shaker at 160 rpm for $72 \mathrm{~h}$ at 24 to $26^{\circ} \mathrm{C}$.

Susceptibility to antibiotics was determined by using the routine diffusion plate technique, plates containing solid medium $\mathrm{B}$, and disks impregnated with following antibiotics: rifampin $(15 \mu \mathrm{g})$, ristomycin $(150 \mu \mathrm{g})$, kanamycin $(10 \mu \mathrm{g})$, ampicillin $(10 \mu \mathrm{g})$, benzylpenicillin $(10 \mu \mathrm{g})$, streptomycin $(15 \mu \mathrm{g})$, neomycin $(15$ $\mu \mathrm{g})$, erythromycin $(15 \mu \mathrm{g})$, gentamicin $(10 \mu \mathrm{g})$, oxacillin $(20 \mu \mathrm{g})$, cephalexin $(10$ $\mu \mathrm{g})$, polymyxin $(50 \mu \mathrm{g})$, lincomycin $(10 \mu \mathrm{g})$, and oflaxacin $(10 \mu \mathrm{g})$.

Genetic analysis. DNA was isolated by the method of Marmur (20). The G+C content of each DNA was determined by the thermal denaturation method of Marmur and Doty (21). Levels of DNA-DNA hybridization were determined spectrophotometrically, and initial renaturation rates were determined as described by De Ley et al. (8) and Levanova et al. (19).

Production and characterization of soluble pigment. Production of a soluble pigment was studied by using medium B and medium BT (medium B supple- 
TABLE 1. Strains studied

\begin{tabular}{|c|c|c|c|}
\hline Species & Strain $^{a}$ & Other designation(s) ${ }^{a}$ & Source $^{a}$ \\
\hline \multirow[t]{11}{*}{ A. nigrifaciens } & KMM 160 & 2MC41 & $\begin{array}{l}\text { Mussel (C. grayanus), Troitza Bay, } \\
\text { Sea of Japan }\end{array}$ \\
\hline & KMM 159 & $2 \mathrm{MC} 45$ & $\begin{array}{l}\text { Mussel (C. grayanus), Troitza Bay, } \\
\text { Sea of Japan }\end{array}$ \\
\hline & KMM 155 & $2 \mathrm{MC} 12$ & $\begin{array}{l}\text { Mussel (C. grayanus), Troitza Bay, } \\
\text { Sea of Japan }\end{array}$ \\
\hline & KMM 154 & 2MC19 & $\begin{array}{l}\text { Mussel (C. grayanus), Troitza Bay, } \\
\text { Sea of Japan }\end{array}$ \\
\hline & KMM 153 & $2 \mathrm{MC} 32$ & $\begin{array}{l}\text { Mussel ( } C \text {. grayanus), Troitza Bay, } \\
\text { Sea of Japan }\end{array}$ \\
\hline & KMM 156 & 2ML26 & $\begin{array}{l}\text { Mussel (C. grayanus), Troitza Bay, } \\
\text { Sea of Japan }\end{array}$ \\
\hline & KMM 298 & 4ML18 & $\begin{array}{l}\text { Mussel (C. grayanus), Troitza Bay, } \\
\text { Sea of Japan }\end{array}$ \\
\hline & KMM 158 & 2MM6 & $\begin{array}{l}\text { Mussel (C. grayanus), Troitza Bay, } \\
\text { Sea of Japan }\end{array}$ \\
\hline & KMM 161 & - & $\begin{array}{l}\text { Mussel (P. jessoensis), Troitza } \\
\text { Bay, Sea of Japan }\end{array}$ \\
\hline & KMM $661^{1^{b}}$ & LMG $2227^{\mathrm{T}}$, NCTC $10691^{\mathrm{T}}$, ATCC $19375^{\mathrm{T}}$, ATCC $23327^{\mathrm{T}}$ & LMG \\
\hline & KMM $661^{\mathrm{T}}$ & IAM $13010^{\mathrm{T}}$, ATCC $19375^{\mathrm{T}}$, NCIMB $8614^{\mathrm{T}}$, NCTC $10691^{\mathrm{T}}$ & U. Simidu \\
\hline A. macleodii & KMM $568^{\mathrm{T}}$ & ATCC $27126^{\mathrm{T}}$, IAM $12920^{\mathrm{T}}$, NCIMB $1963^{\mathrm{T}}$, Baumann $107^{\mathrm{T}}$ & ATCC \\
\hline A. haloplanktis & KMM $460^{\mathrm{T}}$ & $\begin{array}{l}\text { IAM } 12915^{\mathrm{T}}, \text { ATCC } 14393^{\mathrm{T}}, \text { NCIMB } 2084^{\mathrm{T}} \text {, Zobell \& } \\
\text { Upham } 545^{\mathrm{T}}\end{array}$ & U. Simidu \\
\hline A. tetraodonis (A. haloplanktis) & KMM 458 & IAM 14160 & U. Simidu \\
\hline A. carrageenovora & KMM $656^{\mathrm{T}}$ & IAM $12662^{\mathrm{T}}$, ATCC $43555^{\mathrm{T}}$, NCIMB $302^{\mathrm{T}}$ & M. Akagawa-Matsushita \\
\hline A. atlantica & KMM $655^{\mathrm{T}}$ & IAM $12376^{\mathrm{T}}$, IAM $12927^{\mathrm{T}}$, NCIMB $301^{\mathrm{T}}$, ATCC $19262^{\mathrm{T}}$ & M. Akagawa-Matsushita \\
\hline
\end{tabular}

"ATCC, American Type Culture Collection, Rockville, Md.; IAM, Institute of Molecular and Cellular Biosciences (formerly Institute of Applied Microbiology), University of Tokyo, Bunkyo-ku, Tokyo, Japan; KMM, Collection of Marine Microorganisms, Pacific Institute of Bio-Organic Chemistry, Vladivostok, Russia; LMG, Collection of Bacteria of the Laboratory of Microbiology, University of Ghent, Ghent, Belgium; NCIMB, National Collection of Industrial and Marine Bacteria, NCIMB, Ltd., Torry Research Station, Aberdeen, Scotland; NCTC, National Collection of Type Cultures, London, England.

${ }^{b} \mathrm{~T}=$ type strain.

mented with $0.1 \%$ [wt/vol] L-tyrosine). We also used synthetic medium $\mathrm{S}$, which contained $0.05 \%(\mathrm{wt} / \mathrm{vol}) \mathrm{KH}_{2} \mathrm{PO}_{4}, 0.05 \%(\mathrm{wt} / \mathrm{vol}) \mathrm{K}_{2} \mathrm{HPO}_{4}, 0.005 \%(\mathrm{wt} / \mathrm{vol})$ $\mathrm{MgSO}_{4} \cdot 7 \mathrm{H}_{2} \mathrm{O}, 0.06 \%$ (wt/vol) $\mathrm{CuSO}_{4}, 0.005 \%$ (wt/vol) $\mathrm{CaCl}_{2}, 20 \mathrm{mg}$ of Lmethionine, $20 \mathrm{mg}$ of DL-tryptophan; $10 \mathrm{mg}$ of $\alpha$-asparagine, $10 \mathrm{mg}$ of DLphenylalanine, $0.2 \%$ (wt/vol) yeast extract, and $0.1 \%$ (wt/vol) $\left(\mathrm{NH}_{4}\right)_{2} \mathrm{SO}_{4}(\mathrm{pH}$ 7.6); medium ST was medium S supplemented with $0.1 \%$ (wt/vol) I-tyrosine. Basal medium BT was also used with inhibitors of melanogenesis (L-cysteine, EDTA, ascorbic acid). All inhibitors were added at final concentrations of 1 to $10 \mathrm{mM}$. The solubility of pigments was determined with $0.5-\mathrm{ml}$ portions of cultural fluid in 2-ml aliquots of various solvents. Pigments were considered soluble if the solvent was colored after agitation and insoluble if no color was imparted to the solvent.

\section{RESULTS AND DISCUSSION}

Phenotypic characteristics and $G+C$ contents of DNAs. The bacteria isolated from Far Eastern mussels were motile gramnegative rods; each cell had a polar flagellum. Electron micrographs of the bacteria have been published elsewhere (13). Some cells were surrounded by a capsule. No strain accumulated poly- $\beta$-hydroxybutyrate as an intracellular reserve material and had an arginine dihydrolase system. All strains were strictly aerobic (negative in the oxidation-fermentation test) and oxidase positive and required $\mathrm{Na}^{+}$ions or seawater for growth. The strains which we studied differed from the type strain by exhibiting amylase activity and having a wider temperature range for growth. The $\mathrm{G}+\mathrm{C}$ contents of the DNAs ranged from 38.5 to $40.2 \mathrm{~mol} \%$. All of these data suggested that the strains which we isolated belonged to the genus $\mathrm{Al}$ teromonas. The results of an investigation of the phenotypic properties of these organisms (Table 2) allowed us to distinguish them from the nonpigmented species that have similar DNA G $+\mathrm{C}$ contents (A. haloplanktis, A. tetraodonis, Alteromonas atlantica, Alteromonas undina, Alteromonas espejiana) and from Alteromonas carrageenovora. The differential characteris- tics of these species are shown in Table 3. Most of the nine strains isolated from mussels differed from members of other Alteromonas species by utilizing mannose, fructose, sucrose, pyruvate, glycerol, and rhamnose. The strains which we studied had some phenotypic characteristics that differentiated them from the type strain of $A$. nigrifaciens. All of them produced amylase, and most of them grew at $35^{\circ} \mathrm{C}$, utilized mannitol, adonitol, L-ornithine, and L-phenylalanine, and did not utilize citrate and glutarate.

DNA relatedness. The results of our DNA-DNA hybridization experiments are shown in Table 4. The levels of DNADNA relatedness among the strains isolated from mussels ranged from 61 to $100 \%$. These data indicate that the nine strains isolated from mollusks belong to the same species. The levels of DNA-DNA similarity between these organisms and the type strains of Alteromonas macleodii, $A$. haloplanktis, and A. tetraodonis ranged from 12 to $41 \%$. In contrast, the levels of DNA-DNA homology between the type strain $A$. nigrifaciens and the strains isolated from mussels were 66 to $70 \%$. On the basis of the generally accepted criterion (27), we concluded that the strains isolated from mussels were $A$. nigrifaciens strains.

Production of melanin-like soluble pigment. A distinctive feature of $A$. nigrifaciens is its ability to produce a melanin-like pigment (as reflected by the name of the species). The strains which we isolated did not synthesize any pigment when they were grown on common media, such as marine agar 2216 or medium B. We also examined the formation of pigments on tyrosine-containing media that are optimal for melanogenesis by the type strain of $A$. nigrifaciens and on the same media in the presence of inhibitors of melanogenesis, including cysteine, EDTA, and ascorbic acid (Table 5). We found that all of the 
TABLE 2. Characteristics of nine strains of $A$. nigrifaciens isolated from marine mollusks and $A$. nigrifaciens IAM $13010^{\mathrm{T}}$

\begin{tabular}{|c|c|c|c|c|c|c|c|c|c|c|c|}
\hline \multirow{2}{*}{ Characteristic } & \multirow{2}{*}{$\begin{array}{l}\text { KMM } \\
160\end{array}$} & \multirow{2}{*}{$\begin{array}{c}\text { KMM } \\
159\end{array}$} & \multirow{2}{*}{$\begin{array}{c}\text { KMM } \\
158\end{array}$} & \multirow{2}{*}{$\begin{array}{c}\text { KMM } \\
161\end{array}$} & \multirow{2}{*}{$\begin{array}{c}\text { KMM } \\
155\end{array}$} & \multirow{2}{*}{$\begin{array}{c}\text { KMM } \\
153\end{array}$} & \multirow{2}{*}{$\begin{array}{c}\text { KMM } \\
156\end{array}$} & \multirow{2}{*}{$\begin{array}{c}\text { KMM } \\
154\end{array}$} & \multirow{2}{*}{$\begin{array}{c}\text { KMM } \\
294\end{array}$} & $\begin{array}{l}\text { A. nigrifaciens } \\
13010^{\mathrm{T}}\end{array}$ & $\mathrm{AM}$ \\
\hline & & & & & & & & & & $\begin{array}{c}\text { Study of } \\
\text { Baumann et al. }\end{array}$ & $\begin{array}{l}\text { This } \\
\text { study }\end{array}$ \\
\hline Polar flagellum & $t^{b}$ & + & + & + & + & + & + & + & + & + & + \\
\hline Oxidase activity & + & + & + & + & + & + & + & + & + & + & + \\
\hline Pigmentation & - & - & - & - & - & - & - & - & - & + & + \\
\hline $\mathrm{Na}^{+}$required for growth & + & + & + & + & + & + & + & + & + & + & + \\
\hline Requirement for organic growth factors & - & - & - & - & - & - & - & - & - & + & - \\
\hline Arginine dihydrolase activity & - & - & - & - & - & - & - & - & - & - & - \\
\hline Denitrification & - & - & - & - & - & - & - & - & - & - & - \\
\hline Production of: & & & & & & & & & &.. & \\
\hline Gelatinase & + & + & + & + & + & - & + & + & + & + & + \\
\hline Amylase & + & + & + & + & + & + & + & + & + & - & - \\
\hline Lipase & + & + & + & + & + & + & + & + & + & + & + \\
\hline Chitinase & - & - & - & - & - & - & - & - & - & - & - \\
\hline Growth at: & & & & & & & & & & & \\
\hline $4^{\circ} \mathrm{C}$ & - & - & + & + & + & - & + & - & + & + & + \\
\hline $10^{\circ} \mathrm{C}$ & + & + & + & + & + & + & + & + & + & ND & + \\
\hline $28^{\circ} \mathrm{C}$ & + & + & + & + & + & + & + & + & + & ND & + \\
\hline $35^{\circ} \mathrm{C}$ & $\mathrm{v}$ & $\mathrm{v}$ & - & - & + & $\mathrm{v}$ & - & + & - & - & - \\
\hline $41^{\circ} \mathrm{C}$ & - & - & - & - & - & - & - & - & - & - & - \\
\hline Utilization of: & & & & & & & & & & & \\
\hline D-Glucose & + & + & + & + & + & + & + & + & + & ND & + \\
\hline D-Ribose & + & + & + & + & + & - & + & + & + & ND & + \\
\hline D-Xylose & - & + & - & - & - & - & + & + & + & - & + \\
\hline D-Arabinose & + & - & - & - & + & + & + & + & - & - & + \\
\hline D-Rhamnose & - & + & - & - & + & - & + & + & + & - & + \\
\hline D-Mannose & + & - & - & + & + & - & + & + & + & - & + \\
\hline D-Galactose & + & + & + & + & + & + & + & + & + & + & + \\
\hline D-Fructose & + & + & + & + & + & - & + & + & - & + & + \\
\hline Sucrose & + & + & t & t & + & + & - & + & + & - & + \\
\hline Trehalose & + & + & - & + & + & + & + & + & + & ND & + \\
\hline Maltose & + & + & + & + & + & + & - & + & + & ND & + \\
\hline Cellobiose & - & - & - & - & + & + & + & + & - & - & + \\
\hline Lactose & + & - & + & + & - & - & - & + & + & + & + \\
\hline Gluconate & + & + & - & - & - & - & + & + & + & + & + \\
\hline Salicin & - & - & - & - & - & - & - & + & + & - & - \\
\hline Acetate & + & - & - & - & - & - & + & + & + & ND & + \\
\hline Propionate & + & - & + & + & + & + & + & + & + & ND & + \\
\hline Butyrate & + & + & + & + & - & - & + & + & + & + & + \\
\hline Valerate & + & - & + & + & + & + & + & + & + & + & + \\
\hline Caproate & + & - & - & + & + & + & + & + & + & + & + \\
\hline Succinate & + & + & - & + & - & - & + & + & + & + & + \\
\hline Fumarate & + & - & - & - & + & - & - & - & + & + & - \\
\hline$\alpha$-Glutarate & - & - & - & - & - & - & - & - & + & ND & + \\
\hline DL-Lactate & + & + & + & + & + & + & + & + & + & + & + \\
\hline Citrate & - & - & - & - & - & - & - & - & - & + & + \\
\hline$\alpha$-Ketoglutarate & - & - & - & - & - & - & - & - & + & ND & - \\
\hline Pyruvate & + & + & + & + & + & + & + & + & + & ND & + \\
\hline Aconitate & - & + & + & + & + & + & + & + & + & + & + \\
\hline Glycerol & + & - & + & - & - & - & + & + & - & + & + \\
\hline Caprylic acid & - & - & - & - & + & + & + & + & - & ND & - \\
\hline Pelargonic acid & - & - & - & - & - & - & - & - & - & ND & - \\
\hline Glycogen & + & + & + & + & + & + & + & + & + & ND & + \\
\hline Mannitol & + & + & + & + & + & + & + & + & + & - & - \\
\hline D-Sorbitol & + & + & + & + & + & + & + & + & + & ND & + \\
\hline Inositol & + & + & + & + & - & + & + & + & + & ND & - \\
\hline Adonitol & + & + & + & + & - & - & - & - & + & ND & - \\
\hline Ethanol & + & + & - & + & - & + & + & + & + & + & + \\
\hline$p$-Hydroxybenzoate & + & + & + & - & + & + & + & + & + & ND & + \\
\hline Phenylacetic acid & + & + & + & + & - & + & + & + & + & ND & + \\
\hline L- $\alpha$-Alanine & + & + & + & + & + & + & + & - & + & + & + \\
\hline L-Threonine & + & + & + & + & + & + & + & + & + & - & + \\
\hline Aspartic acid & - & - & - & - & - & - & - & - & - & ND & - \\
\hline Glutamic acid & + & - & + & + & + & + & - & + & + & ND & + \\
\hline L-Lysine & + & + & + & + & + & + & + & + & + & - & + \\
\hline L-Arginine & + & + & + & - & + & + & + & + & + & - & + \\
\hline L-Ornithine & + & + & + & + & + & + & + & + & + & - & - \\
\hline
\end{tabular}


TABLE 2-Continued

\begin{tabular}{|c|c|c|c|c|c|c|c|c|c|c|c|}
\hline \multirow{2}{*}{ Characteristic } & \multirow{2}{*}{$\begin{array}{c}\text { KMM } \\
160\end{array}$} & \multirow{2}{*}{$\begin{array}{c}\text { KMM } \\
159\end{array}$} & \multirow{2}{*}{$\begin{array}{c}\text { KMM } \\
158\end{array}$} & \multirow{2}{*}{$\begin{array}{c}\text { KMM } \\
161\end{array}$} & \multirow{2}{*}{$\underset{155}{\mathrm{KMM}}$} & \multirow{2}{*}{$\underset{153}{\mathrm{KMM}}$} & \multirow{2}{*}{$\begin{array}{c}\mathrm{KMM} \\
156\end{array}$} & \multirow{2}{*}{$\underset{154}{\mathrm{KMM}}$} & \multirow{2}{*}{$\begin{array}{c}\text { KMM } \\
294\end{array}$} & \multicolumn{2}{|c|}{$\begin{array}{c}\text { A. nigrifaciens IAM } \\
13010^{\mathrm{T}}\end{array}$} \\
\hline & & & & & & & & & & $\begin{array}{c}\text { Study of } \\
\text { Baumann et al.a }\end{array}$ & $\begin{array}{l}\text { This } \\
\text { study }\end{array}$ \\
\hline L-Histidine & + & + & - & + & - & - & - & + & + & - & + \\
\hline L-Proline & + & - & + & + & + & + & + & - & + & - & + \\
\hline L-Tyrosine & + & + & + & + & + & + & + & + & - & + & + \\
\hline L-Phenylalanine & + & + & + & + & + & + & + & - & - & - & - \\
\hline \multicolumn{12}{|l|}{ Susceptibility to: } \\
\hline Rifampin $(15 \mu \mathrm{g})$ & + & ND & + & + & + & + & + & ND & ND & ND & + \\
\hline Ristomycin $(150 \mu \mathrm{g})$ & - & ND & - & w & + & - & w & ND & ND & ND & - \\
\hline Kanamycin $(10 \mu \mathrm{g})$ & $w$ & ND & - & - & $\mathrm{w}$ & - & $w$ & ND & ND & ND & - \\
\hline Ampicillin $(10 \mu \mathrm{g})$ & + & ND & + & + & + & + & + & ND & ND & ND & + \\
\hline Benzyl-penicillin $(10 \mu \mathrm{g})$ & - & ND & + & - & - & + & + & ND & ND & ND & + \\
\hline Streptomycin $(15 \mu \mathrm{g})$ & + & ND & $\mathrm{w}$ & $\mathrm{w}$ & w & + & + & ND & ND & ND & + \\
\hline Neomycin $(15 \mu \mathrm{g})$ & w & ND & - & - & - & + & + & ND & ND & ND & w \\
\hline Erythromycin $(15 \mu \mathrm{g})$ & + & ND & + & + & + & + & + & ND & ND & ND & + \\
\hline Oxacillin $(20 \mu \mathrm{g})$ & - & ND & - & - & - & - & - & $\mathrm{ND}$ & ND & ND & - \\
\hline Cephalexin $(10 \mu \mathrm{g})$ & - & ND & - & - & - & - & - & ND & ND & ND & - \\
\hline Polymyxin $(50 \mu \mathrm{g})$ & + & ND & + & + & + & + & + & ND & ND & ND & + \\
\hline Lincomycin $(10 \mu \mathrm{g})$ & - & ND & - & - & - & - & -- & ND & ND & ND & - \\
\hline Ofloxacin $(10 \mu \mathrm{g})$ & + & ND & + & $\mathrm{w}$ & $\mathrm{w}$ & + & + & ND & $\mathrm{ND}$ & ND & + \\
\hline
\end{tabular}

${ }^{a}$ Data from reference 6 .

${ }^{b}+$, positive; - , negative; v, variable; ND, no data available; $w$, weakly susceptible.

nonpigmented strains isolated from mussels except strain 2 MC12 produced pigment on media containing tyrosine and were colorless on the media that contained the inhibitors. The pigment extracted from cells with a $0.5 \mathrm{~N} \mathrm{NaOH}$ solution formed a brown solution. The alkaline pigment solution reacted qualitatively like melanin; it became colorless when $\mathrm{H}_{2} \mathrm{O}_{2}$ was added, and addition of $\mathrm{KMnO}_{4}$ resulted in a green solution. The absorption maximum of the pigment $(225 \mathrm{~nm})$ was close to the absorption maximum for synthetic melanin (Sigma) $(223 \mathrm{~nm})$. The data in Table 6 confirmed the melaninlike nature of the pigments tested.

The differences in pigment production and in utilization of some sources of carbon between the strains associated with mussels and other representatives of $A$. nigrifaciens might depend on the habitats of the strains. We found that bacterial associates of mussels had more active hydrolytic enzymes (amylases, gelatinases, lipases, alkaline phosphatases, $\alpha$-galactosidase, etc.) than bacteria isolated from seawater. The most likely reason for these differences is symbiotrophic relationships between bacteria and mussels.

Antimicrobial agent susceptibility. The nine strains of $A$. nigrifaciens examined were susceptible to rifampin, ampicillin, erythromycin, gentamicin, polymyxin, and ofloxacin but were not susceptible to lincomycin, oxacillin, and cephalexin.

Description of $\boldsymbol{A}$. nigrifaciens strains. Only one strain of $A$. nigrifaciens has been described previously (6). This strain was isolated by White (28) and was designated "Pseudomonas nigrifaciens," and it was later renamed because of its close relationship with species belonging to the $A$. haloplanktis rRNA cistron group (26). Detailed phenotypic, genetic, and chemo-

TABLE 3. Differential phenotypic characteristics of Alteromonas species

\begin{tabular}{|c|c|c|c|c|c|c|c|}
\hline Characteristic & $\begin{array}{l}\text { A. haloplanktis } \\
\text { IAM } 12915^{\mathrm{T}}\end{array}$ & $\begin{array}{l}\text { A. ietraodonis } \\
\text { IAM } 14160^{\mathrm{T}}\end{array}$ & $\begin{array}{l}\text { A. atlantica } \\
\text { IAM } 12975^{\mathrm{T}}\end{array}$ & $\begin{array}{l}\text { A. carrageenovora } \\
\text { IAM } 12662^{\mathrm{T}}\end{array}$ & $\begin{array}{l}\text { A. espejiana } \\
\text { IAM } 12640^{\mathrm{T}}\end{array}$ & $\begin{array}{l}\text { A. undina } \\
\text { IAM } 12922^{\mathrm{T}}\end{array}$ & A. nigrifaciens \\
\hline Melanin-like dark pigment ${ }^{a}$ & $t^{b}$ & - & - & + & - & - & d \\
\hline \multicolumn{8}{|l|}{ Production of: } \\
\hline Amylase & - & - & + & - & + & + & + \\
\hline Chitinase & - & - & - & - & - & + & - \\
\hline \multicolumn{8}{|l|}{ Growth at: } \\
\hline $4^{\circ} \mathrm{C}$ & - & - & - & + & - & + & $\mathrm{d}$ \\
\hline $35^{\circ} \mathrm{C}$ & + & + & + & + & + & + & $\mathrm{d}$ \\
\hline \multicolumn{8}{|l|}{ Utilization of: } \\
\hline D-Mannose & - & - & + & - & - & - & + \\
\hline D-Fructose & + & - & + & + & + & - & + \\
\hline Sucrose & - & + & + & + & + & + & + \\
\hline Pyruvate & + & + & + & - & + & - & + \\
\hline Fumarate & + & + & + & + & + & - & - \\
\hline Glycerol & - & - & + & + & + & - & d \\
\hline Rhamnose & - & - & - & - & - & - & d \\
\hline Citrate & + & - & + & + & + & - & - \\
\hline
\end{tabular}

a Data from reference 3 .

${ }^{b}+$, positive; - , negative; d, 11 to $89 \%$ of the strains are positive. 
TABLE 4. Levels of DNA relatedness among strains

\begin{tabular}{|c|c|c|c|c|c|c|c|c|c|}
\hline \multirow[b]{2}{*}{ Strain } & \multirow{2}{*}{$\begin{array}{c}\mathrm{G}+\mathrm{C} \text { content } \\
\quad(\mathrm{mol} \%)\end{array}$} & \multicolumn{8}{|c|}{ \% Hybridization with DNA from: } \\
\hline & & $\begin{array}{c}\text { KMM } \\
160\end{array}$ & $\begin{array}{c}\text { KMM } \\
159\end{array}$ & $\begin{array}{c}\text { KMM } \\
158\end{array}$ & $\begin{array}{c}\text { KMM } \\
161\end{array}$ & $\begin{array}{c}\text { KMM } \\
155\end{array}$ & $\begin{array}{c}\text { KMM } \\
153\end{array}$ & $\begin{array}{c}\text { KMM } \\
156\end{array}$ & $\begin{array}{c}\text { KMM } \\
298\end{array}$ \\
\hline A. nigrifaciens IAM $13010^{\mathrm{T}}$ & 39.2 & 66 & & & & 70 & & & \\
\hline KMM 160 & 39.3 & & 61 & & & 83 & & 92 & \\
\hline KMM 159 & 40.2 & 61 & & & & & & & \\
\hline KMM 158 & 38.5 & & & & & & & 93 & \\
\hline KMM 161 & 39.6 & & & & & & 100 & & \\
\hline KMM 155 & 39.0 & 83 & & & & & & 85 & \\
\hline KMM 153 & 38.5 & & & & & & & 65 & \\
\hline KMM 156 & 39.2 & 92 & & 93 & & & & & 74 \\
\hline KMM 154 & 39.2 & & & 61 & & 100 & & & \\
\hline KMM 298 & 39.5 & & & & & & & 74 & \\
\hline A. macleodii ATCC $27126^{\mathrm{T}}$ & 44.2 & & & & 22 & & 16 & 12 & \\
\hline A. haloplanktis IAM $12915^{\mathrm{T}}$ & 43.4 & & & & & 16 & & 19 & \\
\hline A. tetraodonis IAM $14160^{\mathrm{T}}$ & 36.1 & 29 & & & & 37 & & 41 & \\
\hline A. atlantica IAM $12927^{\mathrm{T}}$ & 41.5 & & & & & & & & 40 \\
\hline A. carrageenovora IAM $12662^{\mathrm{T}}$ & 38.9 & & & & & & & & 36 \\
\hline
\end{tabular}

taxonomic characteristics of Alteromonas nigrifaciens strains isolated from marine animals have not been described previously. The intraspecific variation of the species is discussed below, and an emended description of $A$. nigrifaciens is presented below.

There are no data about capsulated representatives of the genus Alteromonas available. Recently, we described the diversity of the polysaccharides produced by the Alteromonas strains that have been studied (13). The following monosaccharides of $A$. nigrifaciens capsules were identified: D-glucolactylic acid; L-gulosamine uronic acid; L-galactosamine uronic acid; bacillosamine, 4-aminoquinovose acylated with an alanine residue; and 3-aminofucose acylated with a 4-hydroxybutyryl residue. The last $\mathrm{N}$-acyl sugar derivative has not been found previously as a constituent of bacterial polysaccharides. We also examined the susceptibility of cells to antibiotics. The strains which we studied were susceptible to rifampin, ampicillin, erythromycin, gentamicin, polymyxin and ofloxacin but were not susceptible to lincomycin, oxycillin, and cephalexin.

The overall levels of polyamines in A. nigrifaciens were low, but putrescine, cadaverine, and spermidine were present (3a). Small quantities $(0.2$ to $0.6 \mu \mathrm{mol} / \mathrm{g}$ [dry weight] $)$ of 2-hydroxyputrescine and spermine were detected in two strains. Svetashev et al. (24) reported that palmitoleic acid [16:1(n-7)], palmitic acid (16:0), heptadecenoic acid (17:1), and vaccenic acid $[18: 1(\mathrm{n}-7)]$ were the most abundant fatty acids in strains of $A$. nigrifaciens. They also showed that low levels of the branched-chain fatty acids and certain hydroxy fatty acids and the absence of cyclopropane acids are charac- teristic features of these strains as well as of other Alteromonas species.

On the basis of the properties mentioned above, we present the following emended description of $A$. nigrifaciens.

Emended description of Alteromonas nigrifaciens Baumann, Baumann, Bowditch, and Beaman 1984. Alteromonas nigrifaciens (ni.gri.fa'ci.ens. L. adj. niger, black; L. v. facio, to make; M.L. part. adj. nigrifaciens, blackening). Cells are gram-negative, strictly aerobic, straight rods that are 0.8 to $1.2 \mu \mathrm{m}$ wide and 1.8 to $2.3 \mu \mathrm{m}$ long. They are motile by means of a single flagellum at one pole. Some cells are encapsulated. Cells grow at 4 to $30^{\circ} \mathrm{C}$. Some strains grow at $35^{\circ} \mathrm{C}$, but no strain grows at $41^{\circ} \mathrm{C}$. A melanin-like dark pigment is produced by almost all strains in L-tyrosine-containing media, particularly at low temperatures. Produces oxidase and lipase. Sodium ions are required for growth. Growth factors are not required. Chitinase and arginine dihydrolase negative. Does not denitrify. Grows on D-glucose, D-galactose, DL-lactate, pyruvate, D-sorbitol, Lthreonine, and L-lysine. Pelargonate and aspartic acid are not used as sole carbon sources. Susceptible to rifampin, ampicillin, erythromycin, gentamicin, polymyxin, and ofloxacin, but not to lincomycin, oxacillin, and cephalexin. Other biochemical characteristics are shown in Table 3 . The major polyamines are putrescine, cadaverine, and spermidine. The major cellular fatty acids are $16: 1(n-7), 16: 0,17: 1$, and 18:1(n-7). Isolated from seawater and mussels, as well from salted food. The $\mathrm{G}+\mathrm{C}$ content of the DNA is 39 to $41 \mathrm{~mol} \%$.

The type strain is strain KMM 661 (= LMG 2227 = IAM $13010=$ ATCC $19375=$ NCTC 10691).

TABLE 5. Production of melanin-like dark pigments by $A$. nigrifaciens strains in different media

\begin{tabular}{|c|c|c|c|c|c|c|c|c|c|c|}
\hline Medium & $\begin{array}{c}\text { KMM } \\
160\end{array}$ & $\begin{array}{c}\text { KMM } \\
159\end{array}$ & $\begin{array}{c}\text { KMM } \\
158\end{array}$ & $\begin{array}{c}\mathrm{KMM} \\
161\end{array}$ & $\underset{155}{\mathrm{KMM}}$ & $\begin{array}{c}\text { KMM } \\
153\end{array}$ & $\underset{156}{\mathrm{KMM}}$ & $\begin{array}{c}\text { KMM } \\
154\end{array}$ & $\begin{array}{c}\text { KMM } \\
294\end{array}$ & $\begin{array}{l}\text { A. nigrifaciens } \\
\text { IAM } 13010^{\mathrm{T}}\end{array}$ \\
\hline B & $-a$ & - & - & - & - & - & - & - & - & + \\
\hline $\mathrm{BT}$ & w & - & w & + & - & + & + & w & w & + \\
\hline S & - & - & - & - & - & - & - & - & - & + \\
\hline ST & $\mathrm{w}$ & $\mathrm{w}$ & w & + & - & w & + & w & - & + \\
\hline BT + cysteine $(1-10 \mathrm{mM})$ & - & - & - & - & - & - & - & - & - & + \\
\hline $\mathrm{BT}+$ EDTA $(1-10 \mathrm{mM})$ & - & - & - & - & - & - & - & - & - & - \\
\hline
\end{tabular}

${ }^{a}-$, no pigment produced; + , pigment produced; w, weak brown pigment produced. 
TABLE 6. Characterization of pigments produced by $A$. nigrifaciens strains isolated from mollusks

\begin{tabular}{|c|c|c|c|c|c|c|c|c|}
\hline \multirow{2}{*}{ Organism } & \multirow{2}{*}{$\begin{array}{l}\text { Color of } \\
\text { pigment }\end{array}$} & \multicolumn{2}{|c|}{$\begin{array}{l}\text { Solubility of } \\
\text { pigment in }{ }^{a} \text { : }\end{array}$} & \multicolumn{3}{|c|}{ Precipitation of pigment } & \multirow{2}{*}{$\begin{array}{l}\text { Peak }(\mathrm{s}) \text { in } \\
\text { absorption spectrum } \\
(350-650 \mathrm{~nm})\end{array}$} & \multirow{2}{*}{$\begin{array}{c}\text { Tyrosinase } \\
\text { activity }\end{array}$} \\
\hline & & Water & $\begin{array}{l}\mathrm{NaOH} \\
(0.1 \mathrm{M})\end{array}$ & $\begin{array}{c}\text { Blackberg-Wanger } \\
\text { technique }\end{array}$ & $\begin{array}{c}\text { From } \\
\mathrm{NaOH} \text { by } \mathrm{HCl}\end{array}$ & By $\mathrm{FeCl}_{3}$ & & \\
\hline A. nigrifaciens IAM $13010^{\mathrm{T}}$ & Brown & I & $\mathrm{S}$ & $\mathrm{ND}^{b}$ & + & + & ND & ND \\
\hline KMM $160(=2 \mathrm{MC} 41)$ & Brown & I & $\mathrm{S}$ & ND & + & + & ND & ND \\
\hline KMM $159(=2 \mathrm{MC} 45)$ & Brown & I & $\mathrm{S}$ & ND & + & + & ND & ND \\
\hline KMM $158(=2$ MM6) & Brown & I & $\mathrm{S}$ & ND & + & + & ND & ND \\
\hline KMM $161(=3$ GM32) & Brown & I & $\mathrm{S}$ & ND & + & + & 225 & ND \\
\hline KMM $156(==2$ ML26) & Brown & I & $\mathrm{S}$ & ND & + & + & ND & ND \\
\hline Aspergillus nidulans ${ }^{c}$ & Black & I & $\mathrm{S}$ & ND & + & + & 480,535 & ND \\
\hline Shewanella colwelliana ${ }^{d}$ & Brown & I & $\mathrm{S}$ & + & + & + & $223,264,406$ & + \\
\hline
\end{tabular}

${ }^{a} \mathrm{I}$, insoluble; $\mathrm{S}$, soluble.

${ }^{b} \mathrm{ND}$, no data available.

${ }^{c}$ Data from reference 25 .

${ }^{d}$ Data from reference 15

\section{ACKNOWLEDGMENTS}

This study was supported by grants from ISF and by a fellowship grant from the Foreign Researcher Invitation Program of the Agency of Industrial Science and Technology, Japan.

\section{ADDENDUM}

The members of the " $A$. haloplanktis" rRNA cluster and [Pseudomonas] piscicida have been reclassified as separate species of the genus Pseudoalteromonas (10a).

\section{REFERENCES}

1. Aaronson, S. 1970. Procedures for the enrichment and/or isolation of microorganisms, p. 70-103. In Experimental microbial ecology. Academic Press, New York.

2. Akagawa-Matsushita, M., Y. Koga, and K. Yamasato. 1993. DNA relatedness among nonpigmented species of Alteromonas and synonymy of Alteromonas haloplanktis (ZoBell and Upham 1944) Reichelt and Baumann 1973 and Alteromonas tetraodonis Simidu et al. 1990. Int. J. Syst. Bacteriol. 43: 500-503.

3. Akagawa-Matsushita, M., M. Matsuo, Y. Koga, and K. Yamasato. 1992. Alteromonas atlantica $\mathrm{sp}$. nov. and Alteromonas carrageenovora $\mathrm{sp}$. nov., bacteria that decompose algal polysaccharides. Int. J. Syst. Bacteriol. 42:21-627. 3a.Auling, G. Unpublished data.

4. Baumann, L., P. Baumann, M. Mandel, and R. D. Allen. 1972. Taxonomy of aerobic marine eubacteria. J. Bacteriol. 110:402-429.

5. Baumann, P., and L. Baumann. 1981. The marine Gram-negative eubacteria; genera Photobacterium, Beneckea, Alteromonas, Pseudomonas, and Al caligenes, p. 1302-1330. In M. P. Starr, H. Stolp, H. G. Trüper, A. Balows, and H. G. Schlegel (ed.), The prokaryotes. A handbook on habitats, isolation, and identification of bacteria, 1st ed., vol. 2. Springer-Verlag AG, Berlin.

6. Baumann, P., L. Baumann, R. D. Bowditch, and B. Beaman. 1984. Taxonomy of Alteromonas: A. nigrifaciens sp. nov., nom. rev.; $A$. macleodii; and $A$. haloplanktis. Int. J. Syst. Bacteriol. 34:145-149.

7. Baumann, P., M. J. Gauthier, and L. Baumann. 1984. Genus Alteromonas Baumann, Baumann, Mandel and Allen, 1972, 418, p. 243-352. In N. R. Krieg and J. G. Holt (ed.), Bergey's manual of systematic bacteriology, vol. 1. The Williams \& Wilkins Co., Baltimore.

8. De Ley, J., H. Cattoir, and A. Reynaerts. 1970. The quantitative measurement of DNA hybridization from renaturation rates. Eur. J. Biochem. 12: 133-142.

9. Doudoroff, M., and N. J. Palleroni. 1974. Genus Pseudomonas, p. 217-243. In R. E. Buchanan and N. E. Gibbons (ed.), Bergey's manual of determinative bacteriology, 8th ed. The Williams \& Wilkins Co., Baltimore.

10. Enger, O., H. Nygaard, M. Solberg, G. Schel, J. Nielsen, and I. Dundas. 1987. Characterization of Alteromonas denitrificans sp. nov. Int. J. Syst. Bacteriol. 37:416-421.

10a.Gauthier, G., M. Gauthier, and R. Christen. 1995. Phylogenetic analysis of the genera Alteromonas, Shewanella, and Moritella using genes coding for small-subunit rRNA sequences and division of the genus Alteromonas into two genera, Alteromonas (emended) and Pseudoalteromonas gen. nov., and proposal of twelve new species combinations. Int. J. Syst. Bacteriol. 45:755761 .
11. Gauthier, M. J., and V. A. Breittmayer. 1992. The genera Alteromonas and Marinomonas, p. 3046-3070. In A. Balows, H. G. Trüper, M. Dworkin, W. Harder, and K.-H. Schleifer (ed.), The prokaryotes, 2nd ed., vol. 3. SpringerVerlag, New York.

12. International Journal of Systematic Bacteriology. 1981. Validation of the publication of new names and new combinations previously effectively published outside the IJSB. List no. 6. Int. J. Syst. Bacteriol. 31:215-218.

13. Ivanova, E. P., R. P. Gorshkova, V. V. Mikhailov, E. L. Nazarenko, V. A. Zubkov, E. A. Kiprianova, G. F. Levanova, A. D. Galagulya, E. A. Kolesova, and N. M. Gorshkova. 1994. Comparative study of the three marine bacteria strains of the genus Alteromonas and the description of their capsular polysaccharides. Mikrobiologiya 63:228-234. (In Russian.)

14. Johnstone, K. I. 1969. The isolation and cultivation of single organisms. Methods Microbiol. 1:455-471.

15. Kelley, S. K., V. E. Coyne, W. C. Sledjeski, R. M. Fugua, and R. M. Weiner. 1990. Identification of a tyrosinase from a periphytic marine bacterium. FEMS Microbiol. Lett. 67:275-280.

16. Kodama, K., H. Shiozawa, and A. Ishi. 1993. Alteromonas rava sp. nov., a marine bacterium that produces a new antibiotic, thiomarinol. Annu. Rep. Sankyo Res. Lab. 45:131-136.

17. Kovacs, N. 1956. Identificatrion of Pseudomonas pyocyanea by the oxidase reaction. Nature (London) 178:703.

18. Lemos, M. L., A. E. Toranzo, and J. L. Barja. 1985. Modified medium for oxidation-fermentation test in the identification of marine bacteria. Appl. Environ. Microbiol. 40:1541-1543.

19. Levanova, G. F., E. V. Novova, V. N. Sorokina, and E. A. Kiprianova. 1984. Spectrophotometric method of DNA-DNA molecular hybridization for bacteria of the genus Pseudomonas. Biol. Sci. 8:27-32. (In Russian.)

20. Marmur, J. 1961. A procedure for the isolation of deoxyribonucleic acid from microorganisms. J. Mol. Biol. 3:208-218.

21. Marmur, J., and P. Doty. 1962. Determination of the base composition of deoxyribonucleic acid from its thermal denaturation temperature. J. Mol. Biol. 5:109-118.

22. Simidu, U., K. Kita-Tsukamoto, T. Yasumoto, and M. Yotsu. 1990. Taxonomy of four marine bacterial strains that produce tetrodotoxin. Int. J. Syst. Bacteriol. 40:331-336.

23. Smibert, R. M., and N. R. Krieg. 1993. Phenotypic characterization, p. 607-654. In P. Gerhardt, R. G. E. Murray, W. A. Wood, and N. R. Krieg (ed.), Methods for general and molecular bacteriology. American Society for Microbiology, Washington, D.C.

24. Svetashev, V. I., M. V. Vysotskii, E. P. Ivanova, and V. V. Mikhailov. 1995. Gas-liquid chromatographic analysis of cellular fatty acid methyl esters in Alteromonas species. Syst. Appl. Microbiol. 18:37-43.

25. Swan, G. A. 1974. Structure, chemistry and biosynthesis of melanins. Fortschr. Chem. Org. Naturst. 31:521-582.

26. Van Landschoot, A., and J. De Ley. 1983. Intra- and intergeneric similarities of the rRNA cistrons of Alteromonas, Marinomonas (gen. nov.) and some other Gram-negative bacteria. J. Gen. Microbiol. 129:3057-3074.

27. Wayne, L. G., D. J. Brenner, R. R. Colwell, P. A. D. Grimont, O. Kandler, M. I. Krichevsky, L. H. Moore, W. E. C. Moore, R. G. E. Murray, E. Stackebrandt, M. P. Starr, and H. G. Trüper. 1987. Report of the Ad Hoc Committee on Reconciliation of Approaches to Bacterial Systematics. Int. J. Syst. Bacteriol. 37:463-464.

28. White, A. H. 1940. A bacterial discoloration of print butter. Sci. Agric. 20:638-645. 